\title{
Early Traumatic Hepatothorax: An Underdiagnose Complication of High Energy Blunt Trauma
}

\author{
Olival CL da Fonseca Neto ${ }^{1}$, Luiz ER Moutinho ${ }^{2}$, Ludmila RO Costa ${ }^{3}$
}

\begin{abstract}
Aim and objective: This paper reports a case of early traumatic hepatothorax and discusses diagnosis and treatment according to an updated literature review.

Background: Hepatothorax is the abnormal displacement of the liver to the chest. It is a rare condition, which may be challenging to diagnose, and is associated with high energy blunt trauma. Hepatothorax may evolve in different phases: initial, latent, and obstructive; and lead to significant complications and death.

Case description: This paper reports the case of a female patient, 35-year-old, diagnosed with hepatothorax due to a car crash causing a highenergy thoracoabdominal trauma. Due to poor clinical progress after chest drainage, a subsequent helical computerized tomography was done and diagnosed a right diaphragmatic injury and hepatic herniation to the chest. The patient underwent early surgical correction of the diaphragmatic injury and she was later successfully discharged home without complications after a 1-year follow-up.

Conclusion: The literature reports numerous underdiagnosed cases and later surgical correction of traumatic hepatothorax. In this case, persistent dyspnea, despite chest drainage, following a high-energy trauma led to the search and identification of the hepatothorax.

Clinical significance: Physicians should have a high index of suspicion for traumatic hepatothorax in high-energy blunt thoracoabdominal trauma and consider early surgical repair, which is associated with lower morbidity and mortality in this type of injury.
\end{abstract}

Keywords: Blunt trauma, Laparotomy, Traumatic diaphragmatic hernia.

\section{Resumen}

Aim y objetivo: Este relato reporta um caso de hepatotórax traumático precoce e discute o diagnóstico e tratamento de acordo com uma revisão atualizada da literatura.

Introdução: O hepatotórax é definido pelo deslocamento anormal do fígado para o tórax. Trata-se de uma condição rara que pode oferecer dificuldade em termos do diagnóstico e está associado a traumas fechados com grande transferência de energia. O hepatotórax pode evoluir em diferentes fases: inicial, latente e obstrutiva; e conduzir a complicações importantes e a morte.

Relato de caso: Esse artigo relata o caso de uma paciente do sexo feminino, 35 anos, diagnosticada com hepatorórax devido a uma colisão automobilística, que resultou em um trauma toracoabdominal fechado de alta energia. Devido a piora clínica após a drenagem torácica, uma tomografia computadorizada de tórax foi realizada em sequência, e foi diagnosticada uma lesão diafragmática direita associada a herniação hepática para o tórax. A paciente foi submetida a correção cirúrgica precoce da lesão diafragmática e obteve alta hospitalar sem demais complicações até um ano de seguimento.

Conclusão: A literatura abrange vários relatos de casos acerca do hepatotórax traumático inicialmente não diagnosticado associado à correção cirúrgica tardia. Neste caso, a dispneia persistente, apesar da drenagem torácica em seguida de um trauma de grande energia levou à busca ativa e à identificação do hepatotórax.

Significância clínica: O médico emergencista deve manter alto índice de suspeição para o hepatórax traumático em cenário de trauma toracoabdominal fechado com alta transferência de energia e considerar a correção cirúrgica precoce, a qual é associada a menores incidências de morbimortalidade nesse tipo de lesão.

Palabras-clave: Hérnia diafragmática traumática, Trauma fechado, Laparotomia.

Panamerican Journal of Trauma, Critical Care \& Emergency Surgery (2021): 10.5005/jp-journals-10030-1321

\section{BACKGROUND}

Traumatic diaphragmatic hernia is a rare condition $(0.8-1.6 \%$ of hospital admissions for blunt trauma) that occurs with a displacement of the abdominal viscera to the chest. It can be caused by a sharp, penetrating object, as well as by a blunt blow abruptly increasing intra-abdominal pressure. The majority of the diaphragmatic injuries occur on the left side (70-87.5\%) over the unprotected area by the stomach. ${ }^{1}$ However, there are growing reports of high-energy car crashes and right diaphragmatic lesions. ${ }^{2}$ In this context, hepatothorax may occur and patients may present with respiratory and hemodynamic disorders. ${ }^{3}$ In this article, we

\footnotetext{
${ }^{1}$ Department of Trauma Surgery, Hospital da Restauração Governador Paulo Guerra, Recife, Brazil

2,3 Department of Medical Sciences School, University of Pernambuco, Recife, Brazil

Corresponding Author: Luiz ER Moutinho, Department of Medical Sciences School, University of Pernambuco, Recife, Brazil, Phone: +55(81)995992121, e-mail: luiz.moutinho@upe.br

How to cite this article: da Fonseca Neto OCL, Moutinho LER, Costa LRO. Early Traumatic Hepatothorax: An Underdiagnose Complication of High Energy Blunt Trauma. Panam J Trauma Crit Care Emerg Surg 2021;10(2):82-84.
} 
report a traumatic diaphragmatic hernia case associated with hepatothorax, diagnosed and treated early, following blunt trauma.

\section{Case Descriptions}

A 35-year-old woman was hit by a vehicle causing a high-energy blunt trauma to the right side of her body. The patient arrived in the emergency department brought by emergency medical services. The patient reported diffuse chest pain over the right hemithorax. On examination, the airway was patent, $\mathrm{SaO}_{2} 94 \%$ (with low flow $\mathrm{O}_{2}$ supplementation), heart rate $96 \mathrm{bpm}$, Glasgow coma score was 11/15, and Revised Trauma Score (RTS) was 11. Initial assessment indicated polytrauma, possible moderate traumatic brain injury, right humerus fracture, and blunt thoracic trauma. Conventional chest radiography suggested pneumothorax and elevation of the right diaphragm. The chest tube was inserted on the right hemithorax, which drained a large amount of air. Cranial axial tomography revealed no evidence of traumatic brain injury. Despite the chest drainage, the tachypnea persisted (respiratory rate was $27 /$ minute) and a repeated chest $X$-ray showed no improvement of the right diaphragm elevation. Chest and abdomen computerized tomography was performed and showed a herniated right hepatic lobe into the thoracic cavity (Fig. 1). Immediate exploratory laparotomy was performed through a right subcostal incision extended to the left. The surgery confirmed the traumatic hepatothorax with a $12 \mathrm{~cm}$-long diaphragmatic laceration (Fig. 2). The herniated liver was returned to the abdomen, the thoracic cavity was irrigated, a new thoracic drain was inserted under direct vision, the liver right triangular ligament was sutured, and interrupted phrenorrhaphy with synthetic absorbable suture (Fig. 2) was done. No abdominal drain was used. Postoperative recovery was unremarkable and without complications. Seven days after the laparotomy, the patient underwent surgical repair of the humerus and was discharged home seven days later. At 1-year follow-up, the patient remains well without complaints or clinical disorders that can be related to the hepatothorax.

The patient consent form has been obtained and the study protocol was submitted to local ethical board authorization, Comitê de Ética em Pesquisa-Hospital da Restauração (CEP/HR), and approved (CAE: 36733520.9.0000.5198).

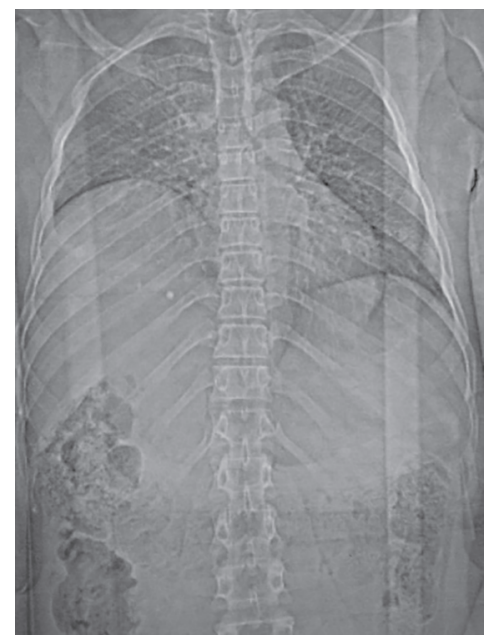

Fig. 1: Coronal CT shows hepatic lobe at the right hemithorax agreeing with traumatic diaphragmatic rupture

\section{Source of support: Nil}

Conflict of interest: None

\section{Discussion}

The present manuscript reports two rare clinical conditions: (1) diaphragmatic lesion, present in $<2 \%$ of the blunt polytrauma patients, ${ }^{4}$ and (2) hepatothorax, present in $0.25-1 \%$ of all blunt abdominal trauma cases. ${ }^{3}$

Post-traumatic transdiaphragmatic hernia occurs mainly due to the higher pressure in the abdominal compartment compared to the intrathoracic pressure. As in this case, $78.1 \%$ of post-traumatic hernias result from automobile crashes. ${ }^{1}$ In contrast to penetrating trauma, diaphragmatic injuries resulting from blunt and highenergy blow are associated with more severe trauma, more injured organs (associated injuries), and larger diaphragmatic lacerations. We performed a review of the MEDLINE (via PubMed) and EMBASE databases for original case reports of traumatic hepatothorax in the last 20 years and found 21 (in 25 publications) according to the following search strategy: ("right diaphragmatic rupture" OR "right DR") AND (hepatothorax OR hepatothorax OR "hepatic hernia*").

The diagnosis of hepatothorax can be difficult in the emergency department due to the non-specificity of radiological signs and clinical symptoms. The injury progression can be defined as initial, latent, or obstructive. The obstructive phase happens with the incarceration and dysfunction of the herniated organs. Indeed, the mortality rates for diaphragmatic injuries are $<5 \%$ when treated early, while delayed treatment may rise to $36-48 \% .{ }^{4}$ Chronic total hepatothorax can lead to periportal edema, venous portosystemic shunt, and torsion of the hepatic hilum. ${ }^{3}$ Hepatothorax may also cause severe restrictive (compression) of the thoracic organs such as lungs, ${ }^{3}$ heart, ${ }^{5}$ and the vena cava. ${ }^{6}$

Several cases in the literature underwent surgical repair years after the initial trauma. ${ }^{3,7-9}$ Negative intrathoracic pressure pulls the liver progressively upwards, provoking early, or delayed, respiratory failure. Late respiratory failure occurs days after the initial trauma, ${ }^{2,10,11}$ though there are reports of respiratory failure occurring $>30$ years after the traumatic event. In some reports, the late presentation of symptomatic hepatothorax was associated with

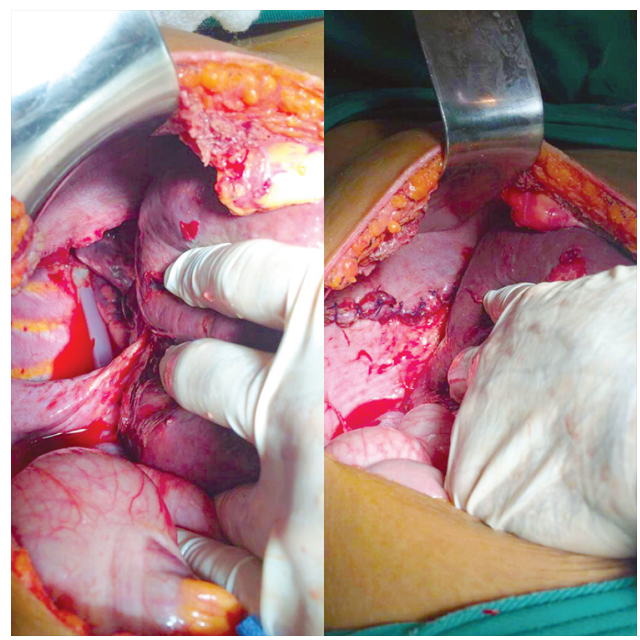

Fig. 2: Cranial view through extended right subcostal incision laparotomy compatible with a diaphragmatic lesion $(12 \mathrm{~cm})$ and herniation of right hepatic lobe (hepatothorax). Discontinuous phrenorrhaphy with absorbable synthetic suture was made 
a perforated peptic ulcer. ${ }^{8,12}$ It is hypothesized that increased intraabdominal pressure caused by peritonitis may cause herniation in previously weakened diaphragmatic regions.

The diagnosis of diaphragmatic lacerations may vary widely according to some papers in $30-61$ and $12-66 \%$ of all cases. $^{3,8}$ Conventional chest radiography is limited to diagnose hepatothorax, being only helpful in $40 \%$ of the cases. However, the elevation of the right hemidiaphragm has a sensitivity $>80 \%$, and progression or persistence of right chest opacity, despite chest drainage, should alert the medical team to the risk of underlying hepatothoraces. Okyere et al. reported two cases in which the persistence of opacity after thoracic drainage, associated with hemodynamic deterioration was relevant in confirming a hepatothorax diagnosis. ${ }^{13}$ Emergency department physicians must pay attention to iatrogenic hepatic injury when carrying out the blind placement of chest tubes. ${ }^{6}$

Helical computed tomography with coronal section reconstruction is the most appropriate method to confirm hepatothorax diagnosis (sensitivity and specificity of 50-90 and 90-100\%, respectively). ${ }^{13,14}$ However, even on chest computerized tomography initial missed diagnoses have been rated between 12 and $63 \% .{ }^{15}$ High clinical suspicion and multiplanar reconstruction might lead to overcome it.

Treatment can be performed via laparotomy or thoracotomy, and simultaneously approaches could be necessary occasionally., ${ }^{9,10,12}$ Associated injuries must be evaluated and, therefore, laparotomy is indicated in early traumatic hepatothorax. Generally, primary sutures using one or two layers are performed; prosthetic materials are used on rare occasions with great loss of tissue. ${ }^{7,13}$ Autologous fascia lata has been used once to repair this type of lesion. ${ }^{11}$ Laparoscopy and thoracoscopy play an increasing role in both late and early treatment of traumatic diaphragmatic hernia and can be considered for the treatment of hepatothorax. ${ }^{7,16}$

\section{Conclusion}

In the reported patient, persistent dyspnea after chest drainage, in a high-energy vehicle trauma, led to the search and identification of a hepatothorax. Helical computed tomography was chosen since the patient was hemodynamically stable. The accurate diagnosis of hepatothorax is often made considering the association of history of a high-energy trauma mechanism, physical examination, and helical computerized tomography imaging. Hepatothorax is an underdiagnosed complication of trauma and a high index of suspicion is required for its diagnosis. Early definitive surgical treatment may prevent hepatothorax progression and late lifethreatening complications.

\section{Presentation(s) or Awards at a Meeting}

The case report abstract was presented in a congress at Fortaleza, Brazil named "XVIII Semana Brasileira do Aparelho Digestivo" on November 25, 2019.

\section{Author Contributions Statement}

Olival CL da Fonseca Neto: clinical management (lead), data curation (lead), writing-review and editing (lead), supervision (lead). Luiz ER Moutinho literature review (lead), writing-original draft (lead), writing-review and editing (supporting), visualization (lead). Ludmila RO Costa data curation (supporting), literature review (supporting), writing-original draft (supporting), visualization (supporting).

\section{Ethical Approval}

The case report protocol was approved by the institution reviewer and Ethical Board in human research (CEP/HR) numbered CAAE 36733520.9.0000.5198 on September 14, 2020. The study was conducted anonymously.

\section{References}

1. Hirano ES, Silva VG, Bortoto JB, et al. Exame radiográfico convencional do tórax no diagnóstico de hérnia diafragmática pós-traumática. Rev Colégio Bras Cir 2012;39(4):280-285. DOI: 10.1590/S010069912012000400007.

2. Igai H, Yokomise H, Kumagai $K$, et al. Delayed hepatothorax due to right-sided traumatic diaphragmatic rupture. Gen Thorac Cardiovasc Surg 2007;55(10):434-436. DOI: 10.1007/s11748-0070158-y.

3. Lugarinho-Monteiro MTRV, Pereira L, Seco C. Chronic hepatothorax due to right diaphragmatic rupture: an anesthetic challenge in a rare case. Rev Bras Anestesiol 2018;68(2):190-193. DOI: 10.1016/j. bjan.2016.02.006.

4. Kumar S, Kumar S, Bhaduri S, et al. An undiagnosed left sided traumatic diaphragmatic hernia presenting as small intestinal strangulation: a case report. Int J Surg Case Rep 2013;4(5):446-448. DOI: 10.1016/j.ijscr.2013.02.006.

5. Topuz M, Ozek MC. Right ventricle collapse secondary to hepatothorax caused by diaphragm rupture due to blunt trauma. Ulus Travma Ve Acil Cerrahi Derg Turk J Trauma Emerg Surg TJTES 2014;20(6):463-465. DOI: 10.5505/tjtes.2014.27547.

6. Bader FG, Hoffmann M, Laubert T, et al. Hepatothorax after right-sided diaphragmatic rupture mimicking a pleural effusion: a case report. Cases J 2009(1):2. DOI: 10.4076/1757-1626-2-8545.

7. Yildar M, Yaman I, Derici H, et al. Laparoscopic repair in simultaneous occurrence of recurrent chronic traumatic diaphragmatic hernia and transdiaphragmatic intercostal hernia. ABCD Arq Bras Cir Dig São Paulo 2015;28(1):90-92. DOI: 10.1590/s0102-67202015000100024.

8. Ebrahimi G, Bloemers FW. A delayed traumatic right diaphragmatic hernia with hepatothorax. J Surg Case Rep 2012;2012(1):1. DOI: 10.1093/jscr/2012.1.1.

9. Guner A, Bekar Y, Kece C, et al. Delayed enterothorax and hepatothorax due to missed right-sided traumatic diaphragmatic rupture. Am J Emerg Med 2012;30(1):263.e7-10. DOI: 10.1016/j. ajem.2010.11.016.

10. Kastanakis M, Anyfantakis D, Kokkinos I, et al. Delayed post-traumatic diaphragmatic rupture complicated by total hepato-thorax: a case report. Int J Surg Case Rep 2013;4(6):537-539. DOI: 10.1016/j. ijscr.2013.03.027.

11. Baloyiannis I, Kouritas VK, Karagiannis K, et al. Isolated right diaphragmatic rupture following blunt trauma. Gen Thorac Cardiovasc Surg 2011;59(11):760-762. DOI: 10.1007/s11748-0100759-8.

12. Quadrozzi F, Favoriti $P$, Favoriti M, et al. Unusual repair in a rare case of hepatothorax due to right-sided diaphragmatic rupture: case report. II G Chir 2016;37(2):84-85. DOI: 10.11138/gchir/2016.37.2.084.

13. Okyere I, Okyere $P$, Glover PSK. Traumatic right diaphragmatic rupture with hepatothorax in Ghana: two rare cases. Pan Afr Med J 2019. 33. DOI: 10.11604/pamj.2019.33.256.17061.

14. AL-Naemi AQ, Khan LA, AL-Naemi l, et al. Traumatic right diaphragmatic rupture with hepatothorax: a diagnostic challenge!. Quant Imaging Med Surg 2015;5(6):930-931. DOI: 10.3978/j.issn.22234292.2015.07.04.

15. Panda A, Kumar A, Gamanagatti S, et al. Traumatic diaphragmatic injury: a review of $C T$ signs and the difference between blunt and penetrating injury. Diagn Interv Radiol 2014;20(2):121-128. DOI: 10.5152/dir.2013.13248.

16. Fiscon V, Portale G, Migliorini G, et al. Laparoscopic repair of intrathoracic liver herniation after traumatic rupture of the diaphragm. Surg Endosc 2011;25(10):3423. DOI: 10.1007/s00464-011$1721-$. 